\title{
Rubella virus and rheumatoid arthritis
}

\author{
HELENA HART AND B. P. MARMION
}

From the Department of Bacteriology, Edinburgh University Medical School, Teviot Place, Edinburgh EH8 $9 A G$

SUMMARY A collection of synovial fibroblasts from 19 patients with rheumatoid arthritis (RA) and 12 patients with osteoarthrosis or other non-RA disease has been examined for rubella virus antigens by immunofluorescence and radioimmunoassay with negative results. Eluates of synovial membrane prepared under conditions likely to dissociate antigen-antibody complexes have shown no rubella antibody. A serological survey of RA patients and those with other forms of arthritis has shown no differences in the frequency or levels of rubella haemagglutination-inhibiting antibody. These results provide little support for various hypotheses that a persistent infection with rubella virus underlies or initiates the rheumatoid process.

The phenomenon of persistent infection with rubella virus is familiar from the congenital rubella syndrome and from some patients with a variety of subacute sclerosing panencephalitis (Townsend et al., 1975; Weil et al., 1975), and also from persistent infection of cultured cells in vitro. The tendency, taken with the observation of a self-limiting synovitis as an occasional complication of acute rubella, lends attraction to a hypothesis that a persistent infection of synovial cells with rubella virus might be the ultimate antigenic stimulus in juvenile (JRA) or adult rheumatoid arthritis (RA).

To test this hypothesis numerous workers have compared the frequency, or mean titre, of rubella antibody in rheumatoid patients with that in control groups of healthy persons, or patients suffering from other forms of arthritis (Chandler et al., 1971; Laitinen et al., 1972; Simsarian et al., 1970; Deinard et al., 1974). These studies have generally failed to show a difference except for those described by Patterson et al., (1973 and personal communication) and Deinard et al. (1974). Other workers have examined antibody from RA synovial fluid cryoprecipitates, or eluates from RA synovial membranes without, however, detecting striking amounts of rubella antibody (Cremer et al., 1974; Zvaifler, 1973).

However, the resolution of rubella virus infection may be protracted in some rheumatoid patients. Thus Ogra, et al. (1975) observed a prolonged infection with rubella virus in some JRA patients,

Accepted for publication 27 April, 1976

Correspondence to Professor B. P. Marmion as judged by high and persistent levels of $\operatorname{IgM}$ and IgG antibody to rubella virus and the demonstration of rubella antigen by immunofluorescence in smears of synovial fluid cells. These effects may be related to the higher prevalence of histocompatibility antigen HLA-B27 in JRA patients (Racheleksfy et al., 1974), with its postulated immunological implications.

An association of persistent rubella infection and adult RA appears to be much less common. A serologically documented case of rubella arthritis progressing to, or associated with, classical adult RA was described by Martenis et al. (1968), who mentioned other patients. More recently, in Edinburgh, a 26-year-old woman has been observed who had an illness resembling rubella and subsequently developed classical RA with positive latex and SSCT tests and a raised erythrocyte sedimentation rate. A raised titre (1/2048-1/4096) of rubella antibody by haemagglutination-inhibition in both the IgG and IgM fractions of her serum was detected early in the illness. The rheumatoid state persisted for 18 months after onset of symptoms when there was a resolution of the symptoms and signs accompanied by a fall in the level of IgM rubella antibody (Duthie et al., unpublished).

Other investigators have approached the problem by trying to show rubella virions or other gene products, or interference by rubella virus, in RA synovial cells, usually fibroblasts. Thus Grayzel and Beck (1970), Smith and Hamerman (1969), and Ford and Oh (1965) found that RA synovial fibroblasts were more resistant to infection with rubella or Newcastle disease viruses than non-RA fibroblasts. This was construed as an intrinsic viral interference, but 
Patterson et al. (1975) and Clarris et al. (1974) have shown that with rubella virus and Newcastle disease virus the apparent resistance of RA synovial fibroblasts is due to a thicker capsule of hyaluronic acid which hinders viral absorption; it can be removed by pretreatment with hyaluronidase.

The mechanism of chronic cellular infection by rubella virus is perhaps not completely understood but presumably involves persistence of infectious virions or viral RNA as cytoplasmic entities transmitted at cell division. Attempts to show infectious rubella virus in RA synovial fibroblasts have been negative by conventional cell culture inoculation, or co-cultivation, as have attempts to show incorporation of radiolabelled uridine into components of fibroblasts with the sedimentation characteristics of rubella RNA or virions (Grayzel, 1973; Person et al., 1973; Norval and Marmion, 1976). Although there appear to be no analogies from cell systems persistently infected with rubella virus, the formal, if slightly heterodox possibility remains that rubella infection of RA synovial cells might take the form of the expression of viral antigens without infectious virions, given, for example, persistence of genetic information in the form of an integrated DNA copy of the RNA viral genome (Sato et al., 1976).

In this context a recent, brief preliminary report by Patterson et al. (1973) was therefore of much interest. These workers, using ${ }^{51} \mathrm{Cr}$ release from cells, complement, and a rubella antiserum from a hyperimmunized rhesus monkey showed (presumptive) rubella antigens on 4 of 6 strains of RA synovial fibroblasts and on a chronically infected cell strain from an infant with the rubella syndrome. Control fibroblasts were negative. This important observation clearly required confirmation, if possible, by other serological techniques. In this paper we report the negative results of attempts to show rubella viruscoded antigens on RA and non-RA synovial fibroblasts by immunofluorescence or radioimmunoassay, and also summarize our own surveys of sera and synovial membrane eluates from RA and nonRA patients for rubella antibody.

\section{Materials and methods}

SYNOVIAL FLUID AND MEMBRANE CULTURES FROM RA OR NON-RA PATIENTS

Fibroblasts from synovial fluids were established by mixing equal volumes of fluid and Eagles Complete Medium (1959 modification). No serum was used at this stage. After 5 days the fluid was replaced by Eagles Complete Medium containing $100 \mathrm{IU} / \mathrm{ml}$ penicillin and $100 \mu \mathrm{g} / \mathrm{ml}$ streptomycin, supplemented with $10 \%$ fetal calf serum (Tissue Culture Services).
Some of the primary cultures were also incubated in the presence of sodium aurothiomalate $10 \mu \mathrm{g} / \mathrm{m} \overline{\mathrm{s}}$. (Myocrisin, 45\% metallic gold, May and Baker, $\vec{\Rightarrow}$ Dagenham, England) and hydrocortisone $36 \mu \mathrm{g} / \mathrm{m}$ ? (Sigma). Sodium aurothiomalate is concentrated within phagocytic cells and inhibits their lysosoma enzyme activity (Persellin and Ziff, 1966); it has alsobeen shown to inhibit the cytotoxic and antitumour cell activity of macrophages (McBride et al., 1975, Ghaffar et al., 1976). Synovial fibroblasts with $\vec{\circ}$ 'nonself' or neoantigens destined for destruction by macrophages might thereby be preserved for examination. Glucocorticosteroids have been re-a ported to increase proliferation of adult humane fibroblasts in vitro and reduce the rate of hyaluronico acid formation (Castor, 1965).

Fibroblasts from synovial membrane were ob $-\dot{\omega}$ tained by overnight trypsinization of synovial tissue $\left(0.25 \%\right.$ trypsin in Dulbecco solution) at $37^{\circ} \mathrm{C}$ and ${ }^{-}$ transfer of the free cells into Eagles Completed Medium containing penicillin and streptomycin with $10 \%$ fetal calf serum. The monolayers of fibroblasts from either source were then propagated by trypsinization. Some of the features of these fibroblast cultures, marked $\mathrm{A}$ to $\mathrm{N}$, in particular their examination for the presence of leucoviruses, are described elsewhere (Norval and Marmion, 1976). Additionals fibroblasts have been used in this study and areō labelled II-XXI.

\section{VIRUSES}

The HPV-77 rubella virus, vaccine strain and a을 recent isolate strain 'Thomas', were kindly supplied by Drs. Gould and Freestone of the Wellcomeo Research Laboratories (Beckenham).

INFECTED AND NONINFECTED CELLS FOR CON-Ö TROLS IN SEROLOGICAL TESTS

A persistent infection was established in the LCC-O $\mathbf{M K}_{2}$ cell line (American Cell Type Collection) with the HPV-77 rubella virus strain and kept on 199의 medium (Wellcome) with $2 \%$ heat inactivated $\left(56^{\circ} \mathrm{C}\right)$ fetal calf serum (FCS). The persistence and글 growth curve of rubella virus in these cells has been described (Maassab et al., 1964) and their use for indirect immunofluorescence has been evaluated 0 (Brown et al., 1964). The infected cells change $\omega$ morphology, becoming sparser, fatter, and more? elongated compared with the uninfected parent cell.o After an initial 3 weeks they were subcultured every 2 weeks. The presence of rubella virus was confirmed ${ }^{?}$ by indirect immunofluorescence (Lennette et al., $\frac{0}{-}$ 1967) and by labelling with ${ }^{3} \mathrm{H}$-uridine (Norval and ${ }_{\mathbb{P}}$ Marmion, 1976). For lytic infection the Thomas or: HPV-77 strain of rubella virus was absorbed on to BHK-21 cells in suspension as described by Lennette 
and Schmidt (1968) and maintained in Eagles Complete Medium with $2 \%$ FCS. For the detection of rubella membrane antigens the virus strains 'Thomas' and HPV-77 were propagated in BHK-21 with Complete Eagles Medium, supplemented with $1 \%$ FCS. The cells were used 4 days after being infected.

\section{LYMPHOCYTES}

Peripheral blood and synovial fluid lymphocytes were separated on Triosil-Ficoll gradients. Synovial fluids were treated with 80 units $/ \mathrm{ml}$ hyaluronidase for $30 \mathrm{~min}$ at $37^{\circ} \mathrm{C}$ before separation on the gradient. Lymphocytes were used at a concentration of $10^{7}$ cells/ml for the immunofluorescence test.

\section{MYCOPLASMA TESTS}

All cultures of synovial fibroblasts or continuous lines were mycoplasma-free except for A from which Mycoplasma orale was cultured.

\section{ANTISER A}

Antisera to HPV-77 rubella were produced by multiple injections of $10 \times$ concentrated supernatant (polyethylene glycol) from $\mathrm{RK}_{13}$ culture (199 medium supplemented with $5 \%$ rabbit serum free of rubella antibody) into New Zealand White rabbits. Initially $5 \mathrm{ml}$ of fluid was given subcutaneously and $1 \mathrm{ml}$ intravenously, followed by 4-weekly injections of $1 \mathrm{ml}$ intravenously (Plotkin, 1969). 2 weeks after the last inoculation the rabbits were bled and their sera tested by the haemagglutinationinhibition test (HAI) for rubella antibodies; this schedule was repeated until their sera had HAI titres of $1 / 1024-2048$. These high titre sera were then absorbed with human liver powder (acetonetreated) and Bentonite particles coated with fetal calf serum (Goodman and Bozicevich, 1964).

\section{CONJUGATES}

For indirect immunofluorescence sheep antirabbit immunoglobulin conjugated with fluorescein isothiocyanate (Wellcome Reagents) was used, diluted $1 / 10$ in $20 \%$ beef brain saline to reduce nonspecific staining. Goat antirabbit immunoglobulin from Nordic Diagnostics Ltd. was used in the radioimmunoassay. It was fractionated on DEAEcellulose DE52 (Reif, 1969); the resulting goat IgG was labelled with ${ }^{125}$ I by the chloramine-T method (Hunter, 1974). The ${ }^{125}$ I was added at a concentration of $500 \mu \mathrm{Ci} / 50 \mu \mathrm{g}$ protein.

\section{IMMUNOFLUORESCENCE}

The indirect immunofluorescence test was performed on acetone-fixed (10 min at room temperature) synovial cells grown on coverslips $(6 \times 22 \mathrm{~mm})$
(Lennette et al., 1967; Schmidt et al., 1966). Some were treated to remove the hyaluronic acid produced by fibroblasts, by including 80 units/ml bovine hyaluronidase (Sigma, Type I) in the complete medium as described by Clarris et al. (1974). Each test included persistently infected $\mathbf{L L C}-\mathbf{M K}_{2}$ cells as a positive control.

To detect rubella virus membrane antigens the virus infected cells were used unfixed, either in suspension (lymphocytes) (Yoshiki et al., 1974), or as fibroblasts grown on coverslips (M. Haire, personal communication). Later, to minimize cell detachment, fixation in $4 \%$ formol-saline for $10 \mathrm{~min}$ was adopted (K. B. Fraser and M. Haire, personal communication), followed by a 30-min wash in phosphate-buffered saline (PBS). After washing, and without drying, the antigen test was carried out using the same method as described for the acetone fixed cells.

\section{SOLID PHASE RADIOIMMUNOASSAY}

In the solid phase radioimmunoassay for antigen (described by Forghani et al., 1974) the virus infected cells and synovial fibroblasts were grown on the bottom of glass vials (controlled neck shell vials, $9.5 / 0.5 \times 48 / 50$, Johnsen and Jorgensen, London) in $0.4 \mathrm{ml}$ of media. The concentration of the cell seed was $20000 / \mathrm{ml}$ media. After 4 days' incubation at $37^{\circ} \mathrm{C}$ the cultures contained approximately 50000 cells per vial. After removal of the growth medium the cells were rinsed with $1 \mathrm{ml}$ of PBS, and then fixed in cold acetone for $10 \mathrm{~min}$ while still wet. The antiserum dilutions were made in PBS supplemented with $2 \%$ FCS. $0.1 \mathrm{ml}$ was then added to each vial and incubated for 2 hours at $37^{\circ} \mathrm{C}$. The contents of the vials were then aspirated and they were washed 4 times in PBS. The 125I conjugate was diluted to contain 60000 counts $/ 100 \mathrm{~s}$ in $0.1 \mathrm{ml}$. This quantity was added to each vial and they were incubated for $80 \mathrm{~min}$ at room temperature. The contents were aspirated and the vials were again washed 4 times. The residual radioactivity was assayed on a gamma counter (Wallac-LKB counting system).

\section{ELUTION OF IMMUNOGLOBULINS FROM SYNOVIAL} MEMBRANES

The method followed that of McCormick et al. (1971). Synovial membranes obtained at operation were finely chopped and were repeatedly washed with PBS pH 7.2. The fluids were checked for adsorption at $280 \mathrm{~nm}$; when this indicated minimal protein, glycine buffer pH $2.510 \mathrm{ml} / \mathrm{g}$ wet tissue was added and stirred at $4^{\circ} \mathrm{C}$ for 2 hours. The 'eluates' were centrifuged immediately at $100000 \mathrm{~g}$ for 1 hour to remove any dissociated 'antigen'. $\mathrm{pH}$ was then adjusted to 7.2 with solid TRIS buffer and the 
fluid dialysed for 72 hours against PBS pH 7.2. Sodium azide at $0 \cdot 1 \%$ concentration was added and the 'eluates' stored at $4^{\circ} \mathrm{C}$ until required for rubella HAI tests. The fluid from the last wash was kept and tested in parallel.

\section{Results}

ATTEMPTS TO DETECT RUBELLA VIRUS ANTIGEN BY IMMUNOFLUORESCENCE

(a) Acetone fixed cells grown on coverslips

The LLC-MK $\mathrm{MK}_{2}$ - cells persistently infected with HPV77 virus showed a granular cytoplasmic staining that sometimes extended round the nucleus, but was mainly located on one side, in the form of bright cytoplasmic inclusions. This type of staining was detected in about $80 \%$ of the persistently infected cells; the number differed according to the number of days after trypsinization and the antiserum dilution used. Such granular cytoplasmic staining was not observed in synovial fibroblasts from any source, either with or without hyaluronidase pretreatment (Table 1). The synovial fibroblasts $\vec{\exists}$ were prepared from 8 classical or definite cases of $\stackrel{0}{?}$ RA, 7 of osteoarthrosis, and one other form of $C$ inflammatory joint disease (non-RA).

(b) Membrane antigens

It was possible to detect membrane antigens on unfixed BHK-21 cells, infected with rubella virus ${ }^{\infty}$ and grown on glass coverslips and also on virus $\bigcirc$ infected cells fixed in formol-saline (Fig. 1). The $\overrightarrow{-}$ latter technique was used on the collection of syno- $\stackrel{\omega}{\circ}$ vial fibroblasts from different sources and all gave negative results irrespective of pretreatment with hyaluronidase (Table 1). It will be noted from Table $\sigma$ 1 that whereas cytoplasmic and membrane staining $\vec{\omega}$ was readily shown with acute infection of BHK fibroblasts, the LLC-MK ${ }_{2}$ cells chronically infected with HPV-77 showed only a weak or no membrane staining.

Table 1 Examination of synovial fibroblasts by immunofluorescence for the cytoplasmic or membrane antigens of rubella virus

\begin{tabular}{|c|c|c|c|c|c|c|c|}
\hline Culture & \multirow{3}{*}{$\begin{array}{l}\text { Diagnosis } \\
\text { RA for } 3 \mathrm{yr}\end{array}$} & \multicolumn{2}{|l|}{ Source } & \multirow{2}{*}{$\begin{array}{l}\text { Tissue } \\
\mathrm{SM}\end{array}$} & \multirow{2}{*}{$\begin{array}{l}\text { Treatment of } \\
\text { fibroblasts }\end{array}$} & \multicolumn{2}{|c|}{$\begin{array}{l}\text { Immunofluorescence } \\
\text { cytoplasmic/membrane }\end{array}$} \\
\hline & & \multirow{2}{*}{\multicolumn{2}{|c|}{ R70 (Dr. Hamerman) }} & & & - & - \\
\hline & & & & & $\mathbf{H}$ & - & - \\
\hline & OA & N104 & "' & SM & $\overline{\mathbf{H}}$ & 二 & . \\
\hline $\mathbf{E}$ & RA for $14 \mathrm{yr}$ & \multirow{2}{*}{\multicolumn{2}{|c|}{$\begin{array}{l}\text { 17/74 (W. Neill) } \\
20 / 74\end{array}$}} & SM & $\mathbf{H}$ & - & $\ddot{ \pm}$ \\
\hline & RA for $14 \mathrm{yr}$ & & & SM & - & - & 二 \\
\hline & & & & & $\mathbf{H}$ & - & \pm \\
\hline \multirow[t]{2}{*}{ G } & OA for $4 \mathrm{yr}$ & $23 / 74$ & $"$ & SM & $\overline{\mathrm{H}}$ & - & \pm \\
\hline & RA for $4 \mathrm{yr}$ & $24 / 74$ & , & SM & - & - & I \\
\hline \multirow[t]{2}{*}{$\mathbf{H}$} & & & & & $\mathbf{H}$ & - & \pm \\
\hline & $\begin{array}{c}\text { Polyarthritis } \\
\text { (non-RA) }\end{array}$ & $25 / 74$ & , & SM & - & - & - \\
\hline \multirow{2}{*}{ I } & & & & & $\mathbf{H}$ & - & - \\
\hline & $\mathrm{RA}$ for $12 \mathrm{yr}$ & $27 / 74$ & " & SM & - & - & - \\
\hline & & & & & $\mathbf{H}$ & - & - \\
\hline & OA for $8 \mathrm{yr}$ & $33 / 74$ & $"$ & SM & $\bar{U}$ & .. & - \\
\hline $\mathbf{K}$ & RA & $42 / 74$ & ," & SM & $\underline{H}$ & 二 & - \\
\hline \multirow[t]{2}{*}{$\mathbf{M}$} & RA & $42 / 14$ & & $\mathrm{SM}$ & $\mathbf{H}$ & - & $\begin{array}{l}. \\
. .\end{array}$ \\
\hline & OA for $3 \mathrm{yr}$ & \multirow{2}{*}{\multicolumn{2}{|c|}{$\begin{array}{l}\text {-(Virus research } \\
\text { group) }\end{array}$}} & SM & - & - & - \\
\hline & & & & & $\mathbf{H}$ & - & - \\
\hline & OA & - & " & $\mathrm{SF}^{*}$ & $\bar{U}$ & - & . \\
\hline \multirow[b]{2}{*}{ W } & $4 \mathrm{yr}$ & & & & $\mathbf{H}$ & - & .. \\
\hline & RA & - & " & $\mathbf{S F}^{* *}$ & $\bar{H}$ & - & $\cdots$ \\
\hline III & $22 \mathrm{yr}$ & & & & $\mathbf{H}$ & - & . \\
\hline \multirow[t]{2}{*}{ IV } & RA & - & $"$ & $\mathbf{S F}^{* *}$ & $\overline{\mathbf{H}}$ & - & $\cdots$ \\
\hline & $4 \frac{1}{2}$ yr & - & " & $\mathrm{SF}^{* *}$ & $\underline{\mathbf{H}}$ & 二 & $\begin{array}{l}. . \\
. .\end{array}$ \\
\hline \multirow{2}{*}{ VI } & $\begin{array}{l}\text { OA } \\
50 \mathrm{yr}\end{array}$ & 一 & & $\mathrm{SF}+4$ & $\mathbf{H}$ & - & .. \\
\hline & OA & - & "' & $\mathbf{S F}^{*}$ & - & - & .. \\
\hline \multirow{3}{*}{ VII } & $8 \mathrm{yr}$ & & & & $\mathbf{H}$ & - & .. \\
\hline & & & & $\mathrm{SF}^{* *}$ & - & - & .. \\
\hline & & & & & $\mathbf{H}$ & - & .. \\
\hline \multirow{4}{*}{$\begin{array}{l}\text { HPV-77-LLC-MK2 } \\
\text { LLC-MK2 } \\
\text { Thomas-BHK-21 } \\
\text { BHK-21 }\end{array}$} & P14 & .. & & Monkey & .. & ++ & - \\
\hline & P12 & .. & & kidney & . & - & - \\
\hline & P8 & .. & & Hamster & . & +++ & ++ \\
\hline & P8 & . & & kidney & .. & - & 一 \\
\hline
\end{tabular}

SM=synovial membrane; $\mathrm{SF}^{*}=$ synovial fluid culture was isolated with hydrocortisone $(36 \mu \mathrm{g} / \mathrm{ml}) ; \mathrm{SF} * *=s y n o v i a l$ fibroblasts were isolated $\mathrm{S}$ in the presence of hydrocortisone and sodium aurothiomalate $(10 \mu \mathrm{g} / \mathrm{ml}) ; \mathrm{H}=$ hyaluronidase $(80 \mathrm{units} / \mathrm{ml}) . \pm$ to $+++=$ increasing degrees of immunofluorescence. $-=$ negative immunofluorescence. $\cdots=$ not tested or no treatment. $P=$ passage level 


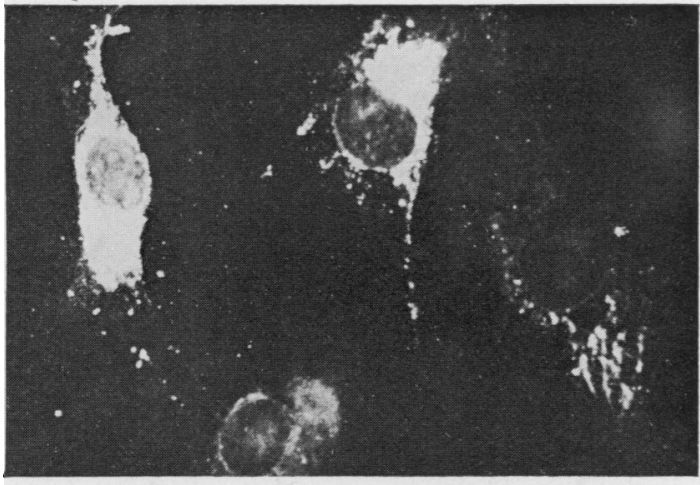

(a)

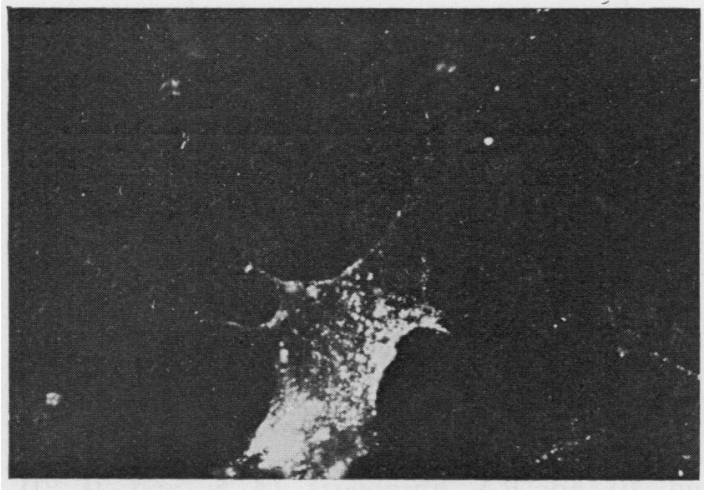

(b)

Fig. 1 (a) Cytoplasmic accumulations of rubella virus antigen in BHK-21 cells, fixed with acetone and stained with rubella antiserum $(R 3 / H P V-77 / 6-14.3 .75)$ at $1 / 5$ dilution. (b) Membrane immunofluorescence of rubella virus in BHK-21, fixed with 4\% formol-saline and stained with the same serum.

Separated lymphocytes from synovial fluid and peripheral blood were treated with hyperimmune rabbit rubella antiserum (R3/HPV-77/6-14.3.75) at $1: 10$ dilution as for membrane antigens. There was no membrane immunofluorescence with 8 lots of synovial lymphocytes from RA patients and one JRA patient. In 2 instances the peripheral blood lymphocytes from the same patient were also treated, but with negative results.

ATTEMPTS TO DETECT RUBELLA VIRUS ANTIGEN BY RADIOIMMUNOASSAY

Solid-phase radioimmunoassay will detect viral antigens in infected cells (Hayashi et al., 1972, 1973; Forghani et al., 1974) and its sensitivity has been shown to be greater than that of immunofluorescence (Hayashi et al., 1973-74). So far as we are aware it has not been applied to the detection of rubella antigens; it was felt that a test of greater sensitivity than immunofluorescence should be used in further attempts to validate the results of Patterson et al. (1973), particularly in view of the failure to show membrane antigens on HPV-77-LLC-MK ${ }_{2}$ by immunofluorescence (Table 1).

\section{Calibration of radioimmunoassay}

The rubella (HPV-77) antiserum (R3/HPV-77/614.3.75) from the hyperimmunized rabbit $R 3$ and its preimmunization serum $(\mathrm{R} 3 / \mathrm{N} 2)$, were titrated by radioimmunoassay on BHK 21 cells acutely infected with the strain 'Thomas' and LLC-MK cells chronically infected with HPV-77. The preimmunization and the antiserum were absorbed with human liver powder, LLC-MK 2 cells, and human diploid fibroblasts; half-log dilutions from $1 / 30$ to $1 / 100000$ of the sera were layered on monolayers on the bottom of glass vials. Goat IgG labelled with ${ }^{125} I$ and containing the antibody against rabbit IgG was used at a dilution giving 60000 counts/ $100 \mathrm{~s}$ in $100 \mu \mathrm{l}$. The resulting titration curves of the two sera on infected and uninfected BHK 21 cells is shown in Fig. 2 and on infected and uninfected LLC-MK $\mathrm{MK}_{2}$ in Fig 3. In each instance the number of counts bound to infected cells treated with antiserum R3/HPV-77/6-14.3.75 was substantially in excess, over the range of dilutions from $1 / 30$ $1 / 3000$, when compared with the same serum on uninfected cells, or the preimmunization serum on

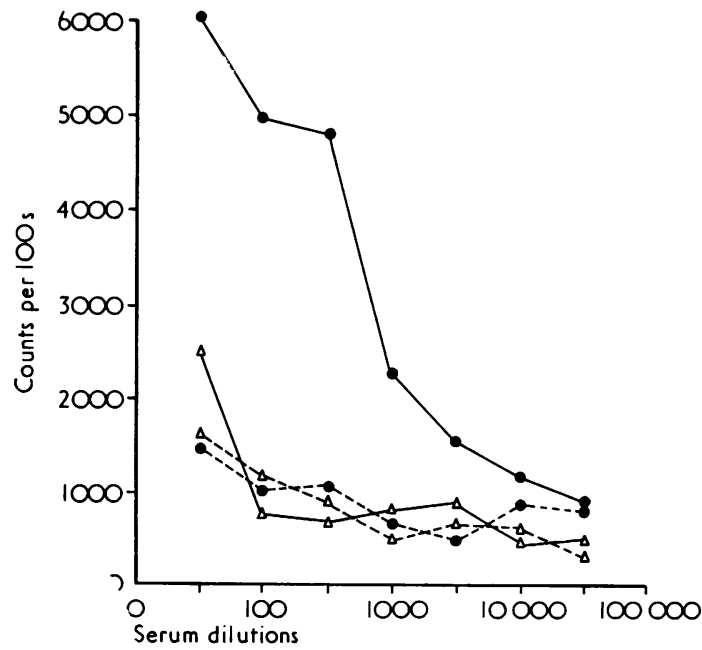

Fig. 2 Effects of a concentration of intermediate serum on binding with rubella antigens. $\bullet$, Thomas-rubella infected BHK-21 cells; $\triangle$, control BHK-21 cells; $\rightarrow, R 3 / H P V-77 / 6-14.3 .75$ hyperimmune rubella antiserum; ---, $R 3 / N 2$ preimmumization serum. 


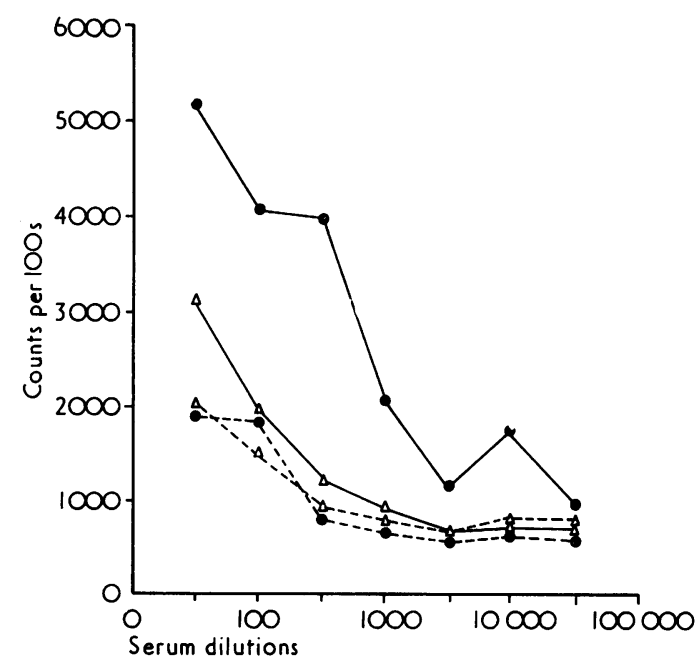

Fig. 3 Radioimmunoassay with hyperimmune anti-rubella rabbit serum. ${ }^{125}$ I-labelled goat antirabbit IgG was used at 60000 counts $/ 100 \mathrm{~s}$., chronically infected LLC-MK2 cells with HPV-77 rubella; $\triangle$, control LLC-MK2 cells; -, hyperimmune antirubella rabbit serum $\mathrm{R} 3 / \mathrm{HPV}-77 / 6-$ 14.3 .75 ; ---, preimmunization serum $R 3 / H P V-77 / N 2$.

infected or uninfected cells. Inspection of the curves suggests a titration end point in the region $1 / 1000$ $1 / 3000$ which approximates to the titre of $1 / 2048$ of the serum measured by HAI before absorption.

An optimal dilution of $1 / 300$ of the antiserum was evident on the basis that the distance separating the antiserum and control curves was greatest at that dilution. Activity at that antiserum dilution on the BHK 21 cell system could be expressed either (i) as a binding ratio of counts/100 $\mathrm{s}$ of serum dilution on virus infected cells divided by counts/100 s on uninfected cells-giving values, respectively, of 6.3 for the immune serum and 1.3 for the preimmune serum-or (ii) as a binding ratio, counts per $100 \mathrm{~s}$ antiserum/counts per $100 \mathrm{~s}$ preimmune serum on the same cells, with values respectively of 4.5 and $<1.0$. The chronically infected HPV-77-LLC-MK cells and the controls gave binding ratios of 4.9 and 1.2 by method (ii). These cells had been infected for one year at that time and were in the 22nd passage $(3.5 \%$ of cells showed immunofluorescence at that stage compared with about $80 \%$ after the initial infection).

Synovial fibroblasts were grown on the bottom of glass vials and exposed to $1 / 100,1 / 300$, and $1 / 1000$ dilutions of the antiserum, or of the corresponding preimmunization serum, and the binding ratios were calculated by method (ii). Fig. 4 shows the distribution of binding ratios for 10 RA synovial fibroblasts

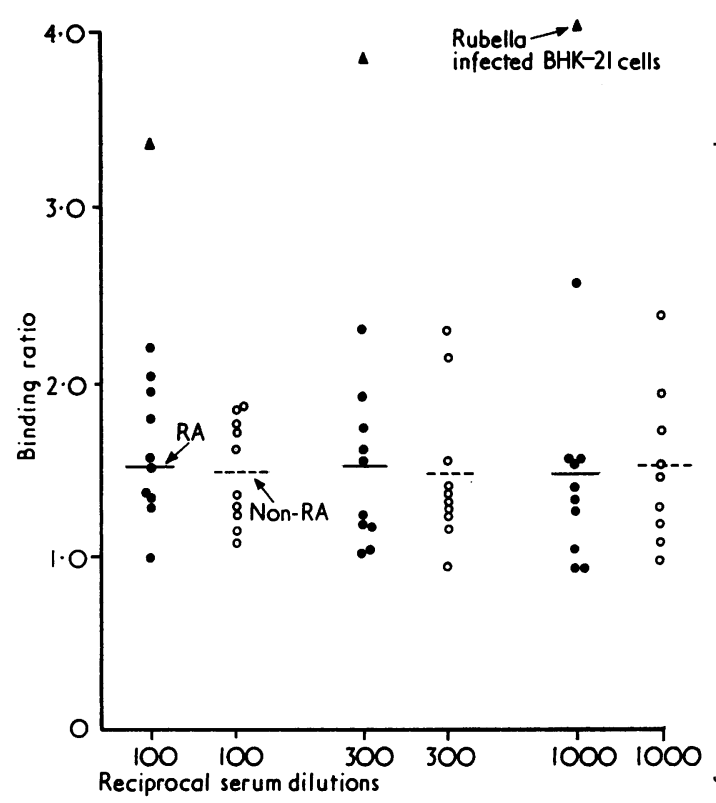

Fig. 4 The binding ratios for each serum dilution (c/100 $s$ for hyperimmune serum R3/HPV-77/6-14.3.75 divided by $c / 100 \mathrm{~s}$ for the preimmunization serum) are plotted in 2 groups: $R A$ fibroblasts ( $\bullet$ ), and non-RA fibroblasts (o) include osteroarthrosis and other forms of inflammatory joint diseases.

and 10 non-RA fibroblasts (A-N and II-VII, $\overrightarrow{\vec{P}}$ Table 1), at the 3 dilutions of serum R1/HPV-77/4-3 7.1.75, and also the ratios obtained with rubella virus infected BHK cells. There was little difference in the distribution of counts bound between RA synovial fibroblasts on the one hand and non-RA? fibroblasts on the other. However, it was known that despite attempts to use a homologous system the antiserum had some activity against calf serum due to problems of residual contamination with calf serum of the antigen for immunizing the rabbit. $\frac{\text { ? }}{3}$ Because of this and also because the collection of $D$ synovial fibroblasts was at a high passage level, some fresh isolates (VIII-XXI) of fibroblasts were estab-N lished and tested with R29/N1 (preimmunization serum) and R29/Thomas/2-23.9.75 (hyperimmune) rabbit antiserum (HAI titre $1: 2048$ ) (see Table 2).

Five samples were used at each dilution and standard deviations were also calculated. Of 110 cultures of fibroblasts from patients with definite RA only one culture had slightly raised binding? ratio (XIX P4). However, a raised binding ratio was ${ }^{\top}$ also found in one culture out of six non-RA fibro- $\frac{\text { + }}{8}$ blasts (N P17). These results do not support the view that rubella antigens are expressed in synovial $\stackrel{\mathbb{Q}}{\Omega}$ fibroblasts from rheumatoid patients. 
Table 2 Examination of hyaluronidase-treated synovial fibroblasts from patients with rheumatoid arthritis, and other joint conditions, for rubella antigens detectable by radioimmunoassay with pre-and postimmunization sera from rabbit 29 given the 'Thomas' strain of rubella virus

\begin{tabular}{|c|c|c|c|c|c|c|}
\hline \multicolumn{2}{|c|}{ Culture no. } & \multirow{2}{*}{ Diagnosis } & \multirow[t]{2}{*}{ Serum dilution } & \multicolumn{2}{|c|}{ Counts bound $( \pm S D)$ with } & \multirow[t]{2}{*}{ Binding ratio } \\
\hline & & & & $\begin{array}{l}\text { Rubella antiserum } \\
\text { (R29/THOMAS/ } \\
2-23.9 .75)\end{array}$ & $\begin{array}{l}\text { Preimmunization } \\
\operatorname{serum}(R 29 / N 1)\end{array}$ & \\
\hline $\mathbf{G}$ & P17 & OA (4 yr) & $\begin{array}{l}1: 100 \\
1: 300 \\
1: 1000\end{array}$ & $\begin{array}{l}529 \pm 238 \\
449 \pm 48 \\
297 \pm 26\end{array}$ & $\begin{array}{l}415 \pm 97 \\
371 \pm 73 \\
326 \pm 43\end{array}$ & $\begin{array}{r}1 \cdot 27 \\
1 \cdot 35 \\
<1\end{array}$ \\
\hline $\mathbf{I}$ & P19 & $\begin{array}{c}\text { Polyarthritis } \\
\text { (non-RA) }\end{array}$ & $\begin{array}{l}1: 100 \\
1: 300 \\
1: 1000\end{array}$ & $\begin{array}{l}597 \pm 110 \\
437 \pm 57 \\
317 \pm 29\end{array}$ & $\begin{array}{l}403 \pm 36 \\
408 \pm 58 \\
310 \pm 8\end{array}$ & $\begin{array}{l}1.48 \\
1.07 \\
1.02\end{array}$ \\
\hline $\mathbf{N}$ & P17 & OA (3 yr) & $\begin{array}{l:l}1: 100 \\
1: 300 \\
1: 1000\end{array}$ & $\begin{array}{l}628 \pm 84 \\
381 \pm 62 \\
309 \pm 45\end{array}$ & $\begin{array}{l}323 \pm 24 \\
281 \pm 22 \\
235 \pm 32\end{array}$ & $\begin{array}{l}1 \cdot 94 \\
1 \cdot 36 \\
1 \cdot 31\end{array}$ \\
\hline $\mathbf{V}$ & P8 & RA (2⿺ yrs) & $\begin{array}{l}1: 100 \\
1: 300 \\
1: 1000\end{array}$ & $\begin{array}{l}699 \pm 51 \\
512 \pm 39 \\
387 \pm 42\end{array}$ & $\begin{array}{l}918 \pm 54 \\
732 \pm 73 \\
525 \pm 53\end{array}$ & $\begin{array}{l}<1 \\
<1 \\
<1\end{array}$ \\
\hline VIII & P7 & OA (8 yr) & $\begin{array}{l}1: 100 \\
1: 300 \\
1: 1000\end{array}$ & $\begin{array}{l}436 \pm 60 \\
336 \pm 63 \\
253 \pm 54\end{array}$ & $\begin{array}{l}577 \pm 63 \\
457 \pm 46 \\
335 \pm 31\end{array}$ & $\begin{array}{l}<1 \\
<1 \\
<1\end{array}$ \\
\hline IX & P6 & RA (3 yr) & $\begin{array}{ll}1: 100 \\
1: 300 \\
1: 1000\end{array}$ & $\begin{array}{l}243 \pm 14 \\
186 \pm 23 \\
180 \pm 111\end{array}$ & $\begin{array}{l}229 \pm 37 \\
261 \pm 46 \\
227 \pm 37\end{array}$ & $\begin{array}{l}1.06 \\
<1 \\
<1\end{array}$ \\
\hline $\mathbf{x}$ & P7 & 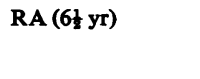 & $\begin{array}{l:l}1 & : 100 \\
1 & : 300 \\
1 & : 1000\end{array}$ & $\begin{array}{l}465 \pm 64 \\
315 \pm 39 \\
309 \pm 172\end{array}$ & $\begin{array}{l}315 \pm 22 \\
288 \pm 36 \\
273 \pm 32\end{array}$ & $\begin{array}{l}1.48 \\
1.09 \\
1.13\end{array}$ \\
\hline $\mathbf{X I}$ & P7 & non-RA (7 yr) & $\begin{array}{ll}1: 100 \\
1: 300 \\
1: 1000\end{array}$ & $\begin{array}{l}302 \pm 26 \\
211 \pm 10 \\
152 \pm 29\end{array}$ & $\begin{array}{l}407 \pm 44 \\
260 \pm 19 \\
170+10\end{array}$ & $\begin{array}{l}<1 \\
<1 \\
<1\end{array}$ \\
\hline XII & P3 & RA (7 yr) & $\begin{array}{l:l}1 & : 100 \\
1 & : 300 \\
1 & : 1000\end{array}$ & $\begin{array}{l}324 \pm 50 \\
252 \pm 31 \\
218 \pm 47\end{array}$ & $\begin{array}{l}518 \pm 97 \\
359 \pm 33 \\
209 \pm 46\end{array}$ & $\begin{array}{l}<1 \\
<1 \\
1.04\end{array}$ \\
\hline XIII & P7 & RA (6 yr) & $\begin{array}{ll}1: 100 \\
1: 300 \\
1: 1000\end{array}$ & $\begin{array}{l}450 \pm 63 \\
316 \pm 67 \\
275 \pm 49\end{array}$ & $\begin{array}{l}760 \pm 67 \\
533 \pm 181 \\
340 \pm 49\end{array}$ & $\begin{array}{l}<1 \\
<1 \\
<1\end{array}$ \\
\hline XIV & P5 & Prob. RA (6 yr) & $\begin{array}{ll}1: & 100 \\
1: 300 \\
1: 1000\end{array}$ & $\begin{array}{l}527 \pm 131 \\
331 \pm 31 \\
277 \pm 41\end{array}$ & $\begin{array}{l}506 \pm 28 \\
367 \pm 45 \\
264 \pm 15\end{array}$ & $\begin{array}{l}1.04 \\
<1 \\
1.05\end{array}$ \\
\hline XV & P4 & RA & $\begin{array}{ll}1 & : 100 \\
1 & : 300 \\
1 & : 1000\end{array}$ & $\begin{array}{l}257 \pm 43 \\
256 \pm 71 \\
219 \pm 33\end{array}$ & $\begin{array}{l}346 \pm 95 \\
313 \pm 44 \\
227 \pm 60\end{array}$ & $\begin{array}{l}<1 \\
<1 \\
<1\end{array}$ \\
\hline XVI & P7 & RA & $\begin{array}{ll}1: 100 \\
1: 300 \\
1: 1000\end{array}$ & $\begin{array}{l}494 \pm 14 \\
346 \pm 61 \\
252 \pm 18\end{array}$ & $\begin{array}{l}505 \pm 119 \\
321 \pm 24 \\
239 \pm 31\end{array}$ & $\begin{array}{l}<1 \\
1.08 \\
1.05\end{array}$ \\
\hline XVII & P7 & RA & $\begin{array}{l}1: 100 \\
1: 300 \\
1: 1000\end{array}$ & $\begin{array}{r}1016 \pm 180 \\
829 \pm 264 \\
818 \pm 108\end{array}$ & $\begin{array}{l}1365 \pm 196 \\
1211 \pm 294 \\
1003 \pm 168\end{array}$ & $\begin{array}{l}<1 \\
<1 \\
<1\end{array}$ \\
\hline XVIII & P5 & $\mathbf{R A}$ & $\begin{array}{l:l}1 & : 100 \\
1 & : 300 \\
1 & : 1000\end{array}$ & $\begin{array}{l}454 \pm 80 \\
339 \pm 24 \\
249 \pm 32\end{array}$ & $\begin{array}{l}503 \pm 64 \\
437 \pm 35 \\
318 \pm 58\end{array}$ & $\begin{array}{l}<1 \\
<1 \\
<1\end{array}$ \\
\hline $\mathbf{X I X}$ & P4 & RA (21 yr) & $\begin{array}{ll}1 & : 100 \\
1 & : 300 \\
1 & : 1000\end{array}$ & $\begin{array}{l}459 \pm 37 \\
374 \pm 57 \\
230 \pm 19\end{array}$ & $\begin{array}{l}295 \pm 30 \\
218 \pm 20 \\
171 \pm 22\end{array}$ & $\begin{array}{l}1 \cdot 56 \\
1 \cdot 72 \\
1 \cdot 35\end{array}$ \\
\hline $\mathbf{x} \mathbf{x}$ & $\mathbf{P 3}$ & RA (10 yr) & $\begin{array}{ll}1 & : 100 \\
1 & : 300 \\
1 & : 1000\end{array}$ & $\begin{array}{l}505 \pm 35 \\
361 \pm 78 \\
261 \pm 40\end{array}$ & $\begin{array}{l}721 \pm 43 \\
512 \pm 29 \\
398 \pm 117\end{array}$ & $\begin{array}{l}<1 \\
<1 \\
<1\end{array}$ \\
\hline $\mathbf{X X I}$ & P5 & $\begin{array}{l}\text { Psoriatic } \\
\text { arthropathy (4 yr) }\end{array}$ & $\begin{array}{l}1: 100 \\
1: 300 \\
1: 1000\end{array}$ & $\begin{array}{l}526 \pm 91 \\
429 \pm 71 \\
395 \pm 35\end{array}$ & $\begin{array}{l}614 \pm 39 \\
435 \pm 46 \\
423 \pm 132\end{array}$ & $\begin{array}{l}<1 \\
<1\end{array}$ \\
\hline \multicolumn{3}{|c|}{$\begin{array}{l}\text { Control } \\
\text { BHK-21 infected with Thomas strain of } \\
\text { rubella virus }\end{array}$} & $\begin{array}{l}1: 100 \\
1: 300 \\
1: 1000\end{array}$ & $\begin{array}{l}1935 \pm 141 \\
1895 \pm 129 \\
1313 \pm 132\end{array}$ & $\begin{array}{l}884 \pm 29 \\
803 \pm 58 \\
702 \pm 110\end{array}$ & $\begin{array}{l}2 \cdot 19 \\
2 \cdot 36 \\
1 \cdot 87\end{array}$ \\
\hline
\end{tabular}


EXAMINATION OF RA SYNOVIAL MEMBRANES FOR BOUND ANTIBODY TO RUBELLA VIRUS

If the antigen-antibody reaction initiating the rheumatoid process were a combination between rubella virus-coded or induced antigens in synovial cells, and locally produced antibody, it might be expected that material eluted from RA membranes under conditions that dissociate antigen-antibody complexes would contain substantial amounts of antibody. This method has been used for example to demonstrate antibody to nucleic acid or Gross leukaemia virus in the kidneys of NZB mice or those chronically infected with lymphocytic choriomeningitis virus (Mellors et al., 1971; Oldstone and Dixon, 1971). This aspect has be zn investigated in collaboration with Dr. J. McCormick. Synovial membrane eluates from 14 patients (13 RA and 1 non-RA) which contained protein demonstrable by adsorption at $280 \mathrm{~nm}$ were tested for a variety of viral antibodies, including those against rubella. All were negative at a dilution of $1 / 4$ in the standard rubella HAI test. This approach is being pursued further with estimations of total immunoglobulins, rheumatoid and antinuclear factors, as well as other specific viral antibodies in the eluates (J. McCormick and $\mathrm{H}$. Hart, to be published).

Table 3 Distribution of haemagglutination-inhibiting (HAI) antibody to rubella virus among patients with rheumatoid arthritis and other arthritic conditions. (Patients with antibody titres $\geqslant 64$ were regarded as positive)

\begin{tabular}{|c|c|c|c|}
\hline Category & $\begin{array}{l}\text { No ir } \\
H A I \\
\leqslant 32\end{array}$ & $\begin{array}{l}\text { with rubella } \\
\text { titres of } \\
\geqslant 64\end{array}$ & Total \\
\hline $\begin{array}{l}\text { Rheumatoid arthritis (RA) } \\
\text { non-RA } \\
\text { Total }\end{array}$ & $\begin{array}{l}49 \\
42 \\
91\end{array}$ & $\begin{array}{l}31 \\
20 \\
51\end{array}$ & $\begin{array}{r}80 \\
62 \\
142\end{array}$ \\
\hline
\end{tabular}

EXAMINATION OF RA AND NON-RA PATIENTS FOR CIRCULATING ANTIBODY TO RUBELLA VIRUS In view of the differences in prevalence rates and geometric mean titres of antibody to rubella virus found in RA patients and healthy individuals by Patterson et al. (1973 and personal communication), we record in Table 3 the results of testing RA and non-RA patients for rubella HAI antibody by standard methods; these figures are extracted from a larger survey done by Susan Baker and workers at the Northern General Hospital and covering a variety of viruses and immunoglobulin fractions. As in numerous previous investigations there was no significant difference between the frequency or levels of rubella antibody in the two groups $(P=0 \cdot 72)$.

\section{Discussion}

There are several ways in which (hypotheticall rubella virus (or other viruses) might be involved in RA; (i) persistence in the $\mathbf{A}$ or $\mathbf{B}$ lining cells vascular endothelium of the synovium, or in cart lage, (ii) generation of antibody cross-reacting wit synovial antigens as a result of viral infection at $\frac{8}{8}$ distant site, (iii) lodgement in the synovium off immune complexes of virus and antibody generated elsewhere in the body, and (iv) viral infection of syn $\sigma_{-}$ vial lymphocytes or macrophages with impairmerge of homoeostatic mechanisms limiting macrophage action (see also Marmion, 1976; Morley, 1974).

The results reported in this paper, together wit. those of Person et al. (1973) and Norval and Marmiont (1976), cover a number of aspects of (i) and (ii) for rubella virus, but as the virus has been found in the cartilage chondrocytes of congenitally infected rabbits (London et al., 1970; Smith et al., 1973) and as this tissue has not been covered in our studies of human RA, investigations of the joint per se are not complete. Possibility (iii) would probably not be covered for rubella virus by the examination \& synovial membrane eluates as the complexes coufd be inside phagocytic cells, or, if free in interstices of the membrane, lost during the washing proces As for possibility (iv), rubella infected lymphocyt have been shown to have a decreased response phytohaemagglutinin stimulation (McMorrow et a 1974; Vesikari and Biumovici-Klein, 1975) an decreased responsiveness to phytohaemagglutin and other antigens has been observed in RA synoviad lymphocytes (G. S. Panayi, personal communic tion; Hedberg et al., 1971; Astorga and Williams, 1969). However, our limited observations on syno vial lymphocytes do not indicate that this anerg is due to the presence of rubella virus coded antigens in the lymphocyte membrane.

This work was supported by a grant from the Nuffield Foundation. We wish to acknowledge the help of Dr. M. Ogilvie; the consultant surgeons at the Princess Margaret Rose Hospital, Edinburgh for providing the synovial membrane specimens and the consultants at the Northern Genera Hospital for the synovial fluid specimens. Synovia strains $\mathbf{A}$ and $\mathbf{D}$ were kindly provided by Dr. IF. Hamerman, and most of the remainder were first cultured at the Northern General Hospital by M.्. W. Neill and in our laboratory by Mr. D. Notmant We also thank Miss Sue Baker (McRobert Fellow supported by the Arthritis and Rheumatism Counc for doing the HAI tests for rubella antibodies, ande Dr. M. Norval for encouragement and the joi interest in synovial fluid lymphocytes. 


\section{References}

Astorga, G. P., and Williams, R. C. (1969). Altered reactivity in mixed lymphocyte culture of lymphocytes from patients with rheumatoid arthritis. Arthritis and Rheumatism, 12, 547-554.

Brown, G. C., Maassab, H. F., Veronelli, J. A., and Francis, T., Jr. (1964). Rubella antibodies in human serum: detection by the indirect fluorescent antibody technique. Science, 145, 943-945.

Castor, C. W. (1965). The effect of chronic glucocorticoid excess on human connective tissue cells in vitro. Journal of Laboratory and Clinical Medicine, 65, 490-499.

Chandler, R. W., Robinson, H., and Masi, A. T. (1971). Serological investigations for evidence of an infectious aetiology of rheumatoid arthritis. Annals of the Rheumatic Diseases, 30, 274-278.

Clarris, B. J., Fraser, J. R. E., and Rodda, S. J. (1974). Effect of cell-bound hyaluronic acid on the infectivity of Newcastle disease virus for human synovial cells in vitro. Annals of the Rheumatic Diseases, 33, 240-242.

Cremer N. E., Hurwitz, D., Quismorio, F. P., Lennette, E. H., and Friou, G. J. (1974). Antiviral antibodies in rheumatoid synovial fluid and cryoprecipitates. Clinical and Experimental Immunology, 18, 27-37.

Deinard, A. S., Venters, H. D., Bilka, P. J., Herrmann, K. L., and Page, A. R. (1974). Rubella antibody titres in rheumatoid arthritis. Lancet, 1, 526-528.

Ford, D. K., and Oh, J. O. (1965). Use of 'synovial' cell cultures in the search for virus in rheumatoid arthritis. Arthritis and Rheumatism, 8, 1047-1052.

Forghani, B., Schmidt, N. J., and Lennette, E. H. (1974). Solid phase radioimmunoassay for identification of herpes virus hominis types 1 and 2 clinical material. Applied Microbiology, 28, 661-667.

Ghaffar, A., McBride, W., and Cullen, R. T. (1976). Interaction of tumour cells and activated macrophages in vitro; modulation by Corynebacterium parvum and gold salt. Journal of the Reticuloendothelial Society, 20, 283-289.

Goodman, H. C., and Bozicevich, J. (1964). Immunological Methods, 1st ed., p. 101. Ed. by J. F. Ackroyd. Blackwell, Oxford.

Grayzel, A. I. (1973). Uridine incorporation into the media and RNA of cultured rheumatoid synovial cells. Arthritis and Rheumatism, 16, 419-421.

Grayzel, A. I. and Beck, C. (1970). Rubella infection of synovial cells and the resistance of cells derived from patients with rheumatoid arthritis. Journal of Experimental Medicine, 131, 367-373.

Hayashi, K., Rosenthal, J., and Notkins, A. L. (1972). Iodine-125-labelled antibody to viral antigens: binding to the surface of virus-infected cells. Science, 176, 516-518.

Hayashi K., Lodmell, D., Rosenthal, J., and Notkins, A. L. (1973). Binding of ${ }^{125}$ I-labelled anti-IgG, rheumatoid factor and anti-C3 to immune complexes on the surface of virus-infected cells. Journal of Immunology, 110, 316-319.

Hayashi, K., Niwa, A., Rosenthal, J., and Notkins, A. L. (1973-1974). Detection of virus-induced membrane and cytoplasmic antigens: comparison of the ${ }^{125}$ I-labelled antiviral antibody binding technique with immunofluorescence. Intervirology, 2, 48-51.

Hedberg, H., Källén, B., Löw, B., and Nilsson, O. (1971). Impaired mixed leucocyte reaction in some different diseases notably multiple sclerosis and various arthritides. Clinical and Experimental Immunology, 9, 201-207.

Hunter, W. M. (1974). Radioimmunoassay. Handbook of Experimental Immunology, 2nd ed., p. 174. Ed. by D. M. Weir. Blackwell, Oxford.
Laitinen, O., Vesikari, T., and Vaheri, A. (1972). Virus antibody levels in RA and SLE. Acta Medica Scandinavica, 192, 37-40.

Lennette, E. H., and Schmidt, N. J. (1968). Development and application of a haemadsorption-inhibition test for rubella virus. Symposia Series in Immunobiological Standardization, 11, 109.

Lennette, E. H., Woodie, J. D., and Schmidt, N. J. (1967)• A modified indirect immunofluorescent staining technique for the demonstration of rubella antibodies in human sera. Journal of Laboratory and Clinical Medicine, 69, 689-695.

London, W. T., Fuccilo, D. A., Anderson, B., and Sever J. L. (1970). Concentration of rubella virus antigen in chondrocytes of congenitally infected rabbits. Nature, 226, 172-173.

McBride, W., Tuach, S., and Marmion, B. P. (1975). The effect of gold salts on tumour immunity and its stimulation by Corynebacterium parvum. British Journal of Cancer, 32, 558-567.

McCormick, J. N., Faulk, W. P., Fox, H., and Fudenberg, H. H. (1971). Immunohistological and elution studies of the human placenta. Journal of Experimental Medicine, 133, 1-18.

McMorrow, L. E., Vesikari, T., Wolman, S. R., Giles, J. P., and Cooper, L. Z. (1974). Suppression of the response of lymphocytes to phytohaemagglutinin in rubella. Journal of Infectious Diseases, 130, 464-469.

Maassab, H. F., Veronelli, J. A., and Hennessy, A. V. (1964). Characteristics of serially propagated cultures with persistent rubella virus infection. Bacteriological Proceedings. 00, 144-145.

Marmion, B. P. (1976). A microbiologist's view of infective hypotheses in rheumatoid arthritis. Infection and Immunity in the Rheumatic Diseases, ed. by D. C. Dumonde. Blackwell, Oxford.

Martenis, T. W., Bland, J. H., and Phillips, C. A. (1968). Rheumatoid arthritis after rubella. Arthritis and Rheumatism, 11, 683-687.

Mellors, R., Shirai, T., Aoki, T., Huebner, R. J., and Krawczynski, K. (1971). Wild type Gross leukemia virus and the pathogenesis of the glomerulonephritis of New Zealand mice. Journal of Experimental Medicine, 133, 113-132.

Morley, J. (1974). Prostaglandins and lymphokines in arthritis-a hypothesis. Prostaglandins, 8, 315-326.

Norval, M., and Marmion, B. P. (1976). Attempts to identify viruses in rheumatoid synovial cells. Annals of the Rheumatic Diseases, 35, 106-113.

Ogra, P. L., Chiba, Y., Ogra, S. S., Dzierba, J. L., and Herd, J. K. (1975). Rubella virus infection in juvenile rheumatoid arthritis. Lancet, 1, 1157-1161.

Oldstone, M. B. A., and Dixon, F. J. (1971). Immune complex disease in chronic viral infections. Journal of Experimental Medicine, 134, 32s-40s.

Patterson, R. L., Howard, F., and Deinhardt, F. (1973). Rubella virus and rheumatoid arthritis. Clinical Research, 21, 878 .

Patterson, R. L., Peterson, D. A., Deinhardt, F. and Howard, F. (1975). Rubella and rheumatoid arthritis: hyaluronic acid and susceptibility of cultured rheumatoid synovial cells to viruses. Proceedings of the Society for Experimental Biology and Medicine, 149, 594-598.

Persellin, R. H., and Ziff, M. (1966). The effect of gold salt on lysosomal enzymes of the peritoneal macrophage. Arthritis and Rheumatism, 9, 57-65.

Person, D. A., Sharp, J. T. and Rawls, W. E. (1973). Attempts to identify viruses and mycoplasmas in connective tissue diseases. Arthritis and Rheumatism, 16, 125-126. 
Plotkin, S. A. (1969). Rubella virus. Diagnostic Procedures for Viral and Rickettsial Infections, 4th ed., p.379. Ed. by E. H. Lennette and N. J. Schmidt. American Public Health Association, New York.

Rachelefsky, G. S., Terasaki, P. I., Katz, R. and Stiehm, E. R. (1974). Increased prevalence of W27 in juvenile rheumatoid arthritis. New England Journal of Medicine, 290, 892-893.

Reif, A. E. (1969). Batch preparation of rabbit $\gamma \mathrm{G}$ globulin with DEAE-cellulose. Immunochemistry, 6, 723-727.

Sato, M., Yamada, T., Yamamoto, K., and Yamamoto, N. (1976). Evidence for hybrid formation between rubella virus and a virus of BHK21/W1-2 cells. Virology, 69, 691-699.

Schmidt, N. J., Lennette, E. H., Woodie, J. D., and Ho, H. H. (1966). Identification of rubella virus isolates by immunofluorescent staining, and a comparison of the sensitivity of three cell culture systems for recovery of virus. Journal of Laboratory and Clinical Medicine, 68, 502-509.

Simsarian, J. P., Roth, H., Hopps, H. E., Douglas, R. D. Williams, M. S., and Meyer, H. M. (1970). Serologic and virologic studies in patients with rheumatoid arthritis. Arthritis and Rheumatism, 13, 348.

Smith, C., and Hamerman, D. (1969). Significance of persistent differences between normal and rheumatoid synovial membrane cells in culture. Arthritis and Rheumatism, 12, 639-654.
Smith, J. L., Early, E. M., London, W. T., Fuccilo, D. A and Sever, J. L. (1973). Persistent rubella virus productio in embryonic rabbit chondrocyte cell cultures. Proceedings of the Society for Experimental Biology and Medicine, 143 1037-1041.

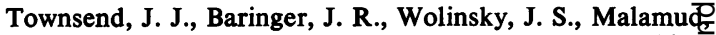
N., Mednick, J. P., Panitch, H. S., Scott, R. A., Oshirō L. S., and Cremer, N. E. (1975). Progressive rubelle panencephalitis-late onset after congenital rubella. Ne England Journal of Medicine, 292, 990-993.

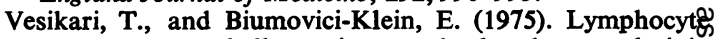
responses to rubella antigen and phytohaemagglutinin. after administration of the RA 27/3 strain of live attenuate $\Phi$ rubella vaccine. Infection and Immunity, 11, 748-753.

Weil, M. L., Ibatashi, H. H., Cremer, N. E., Oshiro, L. Sç Lennette, E. H., and Carnay, L. (1975). Chronic pro gressive panencephalitis due to rubella virus simulatin subacute sclerosing panencephalitis. New England Journat of Medicine, 292, 994-998.

Yoshiki, T., Mellors, R. C., Hardy, W. D., Jr., and Fleissner, E. (1974). Common cell surface antigen associated witbu mammalian C-type RNA viruses. Journal of Experiment $\$$ Medicine, 139, 925-942.

Zvaifler, N. J. (1973). The immunopathology of joint inflammation in rheumatoid arthritis. Advances in Imo munology, 16, 265-336. 